\title{
Using Recyclable Water Containment Areas (RWCAs) to Treat Agricultural Stormwater Runoff For Watersheds: A Concept Paper ${ }^{1}$
}

E.A. Hanlon ${ }^{2}$

\section{Intent}

Retain water within the basin or watershed for the betterment of society, agriculture, and the environment. Develop a means by which private land owners/growers can benefit from assisting with the management of water at the watershed level for control of non-urban stormwater runoff, nutrient sequestering, and soil quality improvement.

\section{Basic concept}

Land within a participating watershed would be selected for water containment. This selected land would persist as a containment area for an agreed time period, say 5 years. The area would have a low berm constructed at its perimeter and within the border ditch/canal system to temporarily impound as much as 2 feet of water throughout the acreage. After that time, the land would be returned to agricultural uses.

\section{Stormwater Treatment Areas (STAs)}

Construction of permanent water impoundments, such as the Stormwater Treatment Areas (STAs) in the Everglades Agricultural Area (EAA) are:

- Costly because of their size (large water structures, berms, etc.), the cost of the land (private to public), and required maintenance.

The STAs typically are 5,000 to 9,000 acres in size.

The land must be publicly owned and generates neither tax funds nor taxable revenue streams. (The STAs may generate some recreational revenues depending upon the ultimate permitted uses.)

While management for nutrient capture is evolving and improving in the STAs, the lifetime of these STAs is limited without drainage and subsequent removal of vegetative matter with resulting disposal requirements.

1. This document is SL227, a fact sheet of the Soil and Water Science Department, Florida Cooperative Extension Service, Institute of Food and Agricultural Sciences, University of Florida. Original publication date July 2005. Visit the EDIS Web Site at http://edis.ifas.ufl.edu.

2. Edward A. Hanlon, Professor, Southwest Florida Research and Education Center, Immokalee, FL 34142-9515, Institute of Food and Agricultural Sciences, University of Florida, Gainesville, FL 32611.

The Institute of Food and Agricultural Sciences (IFAS) is an Equal Opportunity Institution authorized to provide research, educational information and other services only to individuals and institutions that function with non-discrimination with respect to race, creed, color, religion, age, disability, sex, sexual orientation, marital status, national origin, political opinions or affiliations. U.S. Department of Agriculture, Cooperative Extension Service, University of Florida, IFAS, Florida A. \& M. University Cooperative Extension Program, and Boards of County Commissioners Cooperating. Larry Arrington, Dean 


\section{Recyclable Water Containment Areas (RWCAs), a complement to STAs}

\section{The RWCAs will retain water, delaying} discharge from the watershed and slowing flow to tide.

- Work by S. Shukla (UF/IFAS Agricultural and Biological Engineering Department) and colleagues on retention ponds in southwest Florida has shown that approximately $50 \%$ of the water in the pond is lost through lateral and downward movement.

This figure indicates slow release of impounded water from the RWCA to the watershed.

During the onset of the dry season, conventionally constructed retention ponds approach dry surface conditions within 2 to 3 weeks.

2. Water impounded in the RWCA will affect adjacent land through relatively higher water tables.

- This effect is likely to be small, especially during the annual dry season for agricultural crops.

Higher water tables in adjacent land mean more water storage and reduced pumping on any adjacent sub-irrigated lands. Higher water tables in adjacent land also means slower release to those managing the watershed.

For crops such as vegetables, higher water tables in adjacent land may mean more risk due to root damage or possible flooding.

3. Considerable evaporation from the RWCA is likely.

- As water is lost through evaporation, the resulting detritus and nutrients will be deposited on the soil.
- Evaporative water loss from the RWCA will change both discharge volume and timing of that discharge from the watershed.

4. Use of Recyclable Water Containment Areas (RWCAs) can capture nutrients and other plant growth to be used in place after the land is brought back into agricultural production.

- Use of the proposed 5-year cycle ensures that the system on most south Florida soils will not become saturated with nutrients, e.g., phosphorus. (See information regarding the Phosphorus Index in UF/IFAS EDIS documents at http://edis.ifas.ufl.edu/ and the references below)

- All captured nutrients, including nutrients in plants growing within the RWCA, are available for future agricultural plant production.

- The wetting and drying cycle that is likely in these shallow RWCAs will enhance the nutrient capture process and affect many soil chemistry properties (e.g., aerobic with dry conditions to anaerobic with flooding conditions).

- Intermittent flooding may reduce a number of pest insects and diseases, enhancing future agricultural production.

- The land remains in private ownership.

- Fallow rotation is an accepted farming practice if the land is available and costs (e.g., taxes, management, etc.) remain low.

- RWCA concept may help the small grower by contracting with a nearby RWCA owner/operator to handle a portion of water from the small grower's land.

If such a contract were possible, the small grower could use more of his land for production and not have to set aside land for a permanent retention pond. 


\section{Design concepts}

1. Soils with an argillic or spodic horizon will be more effective at holding water and retaining nutrients. However, other soils included in the RWCAs will provide reduced discharge from the watershed and function as a nutrient and plant detritus trap at least to some extent.

- Farm fields that have already been cropped extensively may have elevated nutrient concentrations present, especially phosphorus. The Florida Phosphorus Index (e.g., Hurt et al., 2004) would be a good measure of the farm field for removal of phosphorus from the water column.

- Realistic expectations of phosphorus concentration in discharge waters from RWCAs containing selected soils should be in the 50 to $80 \mathrm{ppb}$ range.

- Treating the soil before construction of the RWCAs with agricultural amendments may enhance nutrient removal from the water.

2. Recent work by UF/IFAS and others has shown that nutrients in canals and farm ditches may contribute to nutrient loading into adjacent water bodies, especially via aquatic plants and associated detritus (Daroub et al., 2002).

Therefore, after designation of the land parcel for an RWCA, ditches and canals should be cleaned. Materials, including plants, should be placed inside the parcel.

3. A temporary perimeter berm should be constructed from soil within the parcel (Figure 1 and Figure 2).

- Care should be exercised to avoid moving too much soil so that neither the spodic nor argillic horizons (if present) are compromised. Rather than digging deep to form the berm, the soil should be moved from a greater surface area to the berm.

- Safe construction of the berm is beyond this conceptual presentation and is not given herein.
4. Outfalls from this area should be constructed so as to restrict movement of particulate matter from the site.

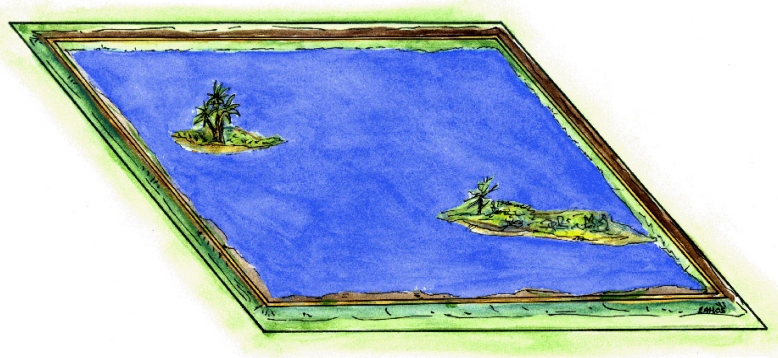

Figure 1. Conceptual drawing of relatively flat field used for a Recyclable Water Containment Area.
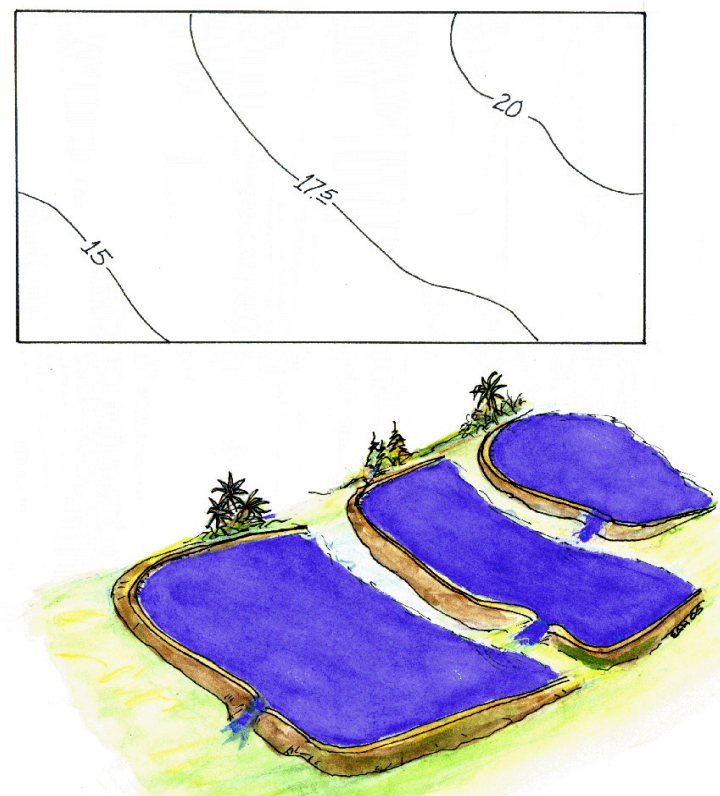

Figure 2. On land that is sloping (see rectangular elevation map at the top of the figure), berms can be aligned with the topographical features to increase water storage capacity within the Recyclable Water Containment Area.

\section{Economics (not in a priority order)}

The following costs should be considered in discussion of RWCA concept:

- Construction of temporary perimeter berms and their subsequent deconstruction; 
- The distance and method for conveyance of water to the RWCA;

- The possibility for using RWCAs to offset the costly requirement of a permanent retention pond;

- Loss of normal cropping and associated revenue;

Perhaps the land in the flooded state could be used for cropping (e.g., rice, native wetland species nursery, waterfowl habitat, etc.);

- Size of the property, elevation changes, and related benefit to water quantity/quality issues in the watershed;

- Adjacent cropping patterns (e.g., citrus, vegetables, sugarcane);

- Type of soil(s) in the proposed parcel;

- Effects of existing retention/detention/irrigation structures on the proposed RWCA;

- Taxes on private land used for an RWCA;

- Pest control (e.g., mosquitoes) if the RWCA is close to human populations or other susceptible species;

- Grower acceptance of an RWCA (i.e., use of private land for the public good) should be voluntary, not a practice that all growers must adopt.

\section{Additional Considerations}

Recently, the South Florida Water Management District released information as a part of the district-wide Acceler8 program at http://xlr8.sfwmd.gov/portal/page?_pageid=35, 226338\&_dad=portal\&_schema $=$ PORTAL, (site verified 28 April 2005) dealing with the C-43 West Basin (Berry Groves property). Dr. J. Capece, Southern DataStream, Inc., used this information to estimate the cost of storing one-acre-foot per year for the 50-year proposed life of this project.

- Large works of the district, such as the C-43 West Basin storage project, are a necessary part of managing water in southern Florida.
- The South Florida Water Management District estimates that the C-43 West Basin will address only one-third of the calculated required storage capacity within the $\mathrm{C}-43$ Basin.

- This information is the first time that water storage costs have been available.

Assuming that no liner is used in the reservoir, the annual storage cost is $\$ 330$ per acre-foot per year.

If a clay liner is ultimately required, based on average costs from governmental sources, the annual storage cost increases to $\$ 420$ per acre-foot per year.

If a plastic liner is required, the annual cost increases to more than $\$ 620$.

- If all or a portion of this storage cost were also made available in the form of payments to growers/landowners using the RWCA approach, then removal of the land for water storage purposes becomes more economically feasible for private landowners.

\section{References}

Daroub, S.H., J.D. Stuck, T.A. Lang, and O.A. Diaz. 2002. Particulate Phosphorus in the Everglades Agricultural Area: I -- Introduction and Sources. EDIS document SL197, http://edis.ifas.ufl.edu/SS410.

Hurt, G.W., R.S. Mylavarapu, and S.P. Boetger. 2004. UF/IFAS Nutrient Management Series: Computational Tools for Field Implementation of the Florida Phosphorus Index, http://edis.ifas.ufl.edu/ TOPIC_SERIES_Florida_Phosphorous_Index. 